\title{
Silverleaf whitefly-resistant common beans: an investigation of antibiosis and/or antixenosis
}

\author{
Thais Lohaine Braga dos Santos 1,* (D), Edson Luiz Lopes Baldin ${ }^{1}$ (D), Leandro do Prado Ribeiro² (D), \\ Camila Moreira de Souza ${ }^{1}$ (D) , Nádia Maebara Bueno ${ }^{1}$ (D) , Ivana Fernandes da Silva ${ }^{1}$ (D) \\ 1.Universidade Estadual Paulista “Júlio de Mesquita Filho” - Faculdade de Ciências Agronômicas - Departamento de Proteção \\ Vegetal - Botucatu (SP), Brazil. \\ 2.Empresa de Pesquisa Agropecuária e Extensão Rural de Santa Catarina - Centro de Pesquisa para Agricultura Familiar - \\ Chapecó (SC), Brazil.
}

\begin{abstract}
The silverleaf whitefly Bemisia tabaci biotype B is one of the most important sucking pests of common bean, which causes severe damages and requires frequently synthetic insecticides spraying to protect crop productivity. The use of common bean cultivars resistant to whitefly attack is an important strategy within an integrated pest management (IPM) program. The biological development of $B$. tabaci confined to 17 bean genotypes was evaluated in greenhouse trials to verify the occurrence of antibiosis. Whitefly adults were released on plants of these genotypes to oviposit, afterward the incubation period of eggs, nymphal period, complete development period (egg-adult), and viability of the silverleaf whitefly nymphs were recorded. As main results, genotype CHIP 300 prolonged the developmental period from egg to adult ( 10 days) and BRS Estilo, Arcelina 4, IPR Garça, Tybatã, CHIP 300, IPR Eldorado, H96A102-1-1-1-52, SCS-202-Guará and CHIB 06 caused nymphal mortality, suggesting high levels of antibiosis and/or antixenosis. These genotypes may be helpful in common bean breeding programs aimed at developing commercial cultivars resistant to B. tabaci biotype B.
\end{abstract}

Key words: antibiosis, host plant resistance, Phaseolus vulgaris L., Bemisia tabaci biotype B.

\author{
Received: \\ Aug. 09, 2019 \\ Accepted: \\ Dec. 17, 2019 \\ Section Editor: \\ Luis Garrigós Leite \\ ${ }^{*}$ Correspondence author: \\ thais_lohaine@hotmail.com
}

\section{INTRODUCTION}

Common bean (Phaseolus vulgaris L., Fabaceae) has great socioeconomic importance in Brazil, being widely consumed as a source of proteins and minerals for people's diet (Carvalho et al. 2014), and besides that, it is a source of income for thousands of agricultural producers, especially family farmers (FAO 2015). The occurrence of insect pests and diseases of common bean are one of the main causes for the reduction of bean productivity (Moraes et al. 2006; Costa et al. 2018).

The silverleaf whitefly, Bemisia tabaci (Gennadius 1889) (Hemiptera: Aleyrodidae) biotype B, is one of the main sucking pests that colonize common bean crops (Musa and Ren 2005; Boykin et al. 2018). Bemisia tabaci is considered a complex of cryptic species that are morphologically indistinguishable, with a total of 43 identified species (De Barro et al. 2011; Tay et al. 2017). Some authors considered biotype B as Middle East-Asia Minor 1 (MEAM1) (Dinsdale et al. 2010; De Barro et al. 2011). However, the authors of the present study chose to use the older nomenclature that is still adopted by many researchers.

Bemisia tabaci biotype $\mathrm{B}$ can cause severe direct and indirect damage to the plants. The direct injury is due to feeding of nymphs and adults, which suck the phloem sap and inject toxins, impairing the vegetative and reproductive development of the plants (Villas Bôas 2005). Due to the large volume of honeydew excreted during feeding, there is usually an increase in the incidence of sooty mold (Capnodium sp.), with negative impacts on photosynthesis and crop productivity (Musa and 
Ren 2005; Naranjo and Legg 2010). In addition, B. tabaci biotype B is an important vector of pathogens, as it can transmit virus species of various genera such as the Bean golden mosaic virus, which can cause losses of up to $100 \%$ in production (Garrido-Ramirez et al. 2000; Aragão and Faria 2009).

The management of silverleaf whitefly in common beans has been carried out almost exclusively using synthetic insecticides from different chemical groups. However, there are several reports of resistance of whitefly populations to active ingredients, jeopardizing the effectiveness of this control tactic (Horowitz et al. 2002; Alon et al. 2008; Houndete et al. 2010; Ma et al. 2010). Moreover, the abusive use of synthetic insecticides can negatively impact the environment, in particular the systemic insecticides that act by contact and ingestion (neonicotinoids based), cause undesirable effects on nontarget organisms, pollinators and natural enemies, as well as their leaching capacity in groundwater (Desneux et al. 2007; Furlan and Kreutzweiser 2015; Alford and Krupke 2017). Thereby, around the only control method used, it makes necessary searching for new control strategies in an efficient and environmentally safe manner, according to the integrated pest management (IPM) precepts. The IPM is a dominant paradigm that guides most aspects of implementation of insect pest management, whose philosophy and history are well documented (Perkins 1982; Kogan 1998; Pedigo 2002).

Among alternative methods to chemical control, genetic resistance is highlighted through the cultivation of resistant genotypes (Smith 2005), which allows the maintenance of the pest population below the level of economic damage being highly compatible with other management tactics (Panda and Khush 1995; Smith and Clement 2012). Resistance is divided into three categories: antixenosis, antibiosis, and tolerance (Painter 1951), the latter being less common (Smith 2005). During this process there are behavioral or biological changes in the insects, and, in other cases, there may be a reaction of the plant itself, but without even affect the pest-insect (Lara 1991). Antibiosis appear when the plant adversely affects the biology of the insect that attempts to use it as food, interfering in its cycle of development, reproduction, and survival, among other biological parameters (Painter 1951; Panda and Khush 1995; Smith 2005; Baldin and Beneduzzi 2010). Antibiotic genotypes generally promote high mortality in the early stages, reduction of adult fecundity, reduction in larval and nymph size and weight, and prolongation of the immature phase (Panda and Klush 1995). The present study focused on the category antibiosis-resistance.

However, studies involving the characterization of bean genotypes on whitefly still have not evaluated a wide range of germplasm (Oriani and Lara 2000; Oriani et al. 2005; Torres et al. 2012; Peixoto and Boiça Júnior 2014; Silva et al. 2014), which motivated the conduction of the present study. Some genotypes of $P$. vulgaris have already been evaluated for resistance to B. tabaci biotype B, and some have been characterized as having antixenotic and/or antibiotic factors (Oriani et al. 2005, Torres et al. 2012; Peixoto and Boiça Júnior 2014; Silva et al. 2014).

Thus, this study evaluated the biological performance of $B$. tabaci biotype $B$ confined to 17 genotypes previous selected from 78 genotypes, in order to characterize the possible expression of antibiosis.

\section{MATERIAL AND METHODS}

The study was carried out in a greenhouse in Botucatu, SP, Brazil ( $\left.22^{\circ} 85^{\prime} \mathrm{S}, 48^{\circ} 26^{\prime} \mathrm{W}\right)$, between November and December 2017. The experiments were conducted in the greenhouse under partially controlled conditions (temperature of $25.68^{\circ} \mathrm{C}$ with a maximum of $35.99^{\circ} \mathrm{C}$ and minimum of $15.37^{\circ} \mathrm{C}$, mean relative humidity of $59 \pm 10 \%$, and natural light).

\section{Obtaining the genotypes}

The 17 bean genotypes used in this study (Table 1) were selected from preliminary trials with B. tabaci (Santos 2018). The commercial genotype 'Pérola' was included as a whitefly susceptibility standard (Silva et al. 2014). The genotypes were provided by the Agronomic Institute of Campinas (IAC), SP, Brazil, and by the Agricultural Research and Rural Extension Company of Santa Catarina (EPAGRI), Chapecó, SC, Brazil, and are a part of the Germplasm Banks of these institutions. Before their use in the trials, the genotypes were grown in pots $(1.7 \mathrm{~L})$ containing a mixture of soil (dark red latosol), 
washed coarse sand, and autoclaved organic matter (tanned manure), in a ratio of 1:1:1 (v/v/v), and commercial substrate (Plantamax, Joinville, SC, Brazil) in a ratio of 3:1 (v/v). The plants were housed in a greenhouse, free from insect infestation, and received the fertilization recommended for the crop (Fancelli 2010). When they reached the phenological stage V3-V4 (Valle et al. 2012), the plants were used in the trials.

Table 1. Common bean genotypes (Phaseolus vulgaris L., Fabaceae) evaluated for resistance to Bemisia tabaci biotype B and their respective genealogies.

\begin{tabular}{|c|c|c|c|}
\hline Genotype & Germplasm bank & Genealogy/Origin/Characteristics & Resistance history \\
\hline BRS Esplendor & EMBRAPA & It originated from the crossing CB911863/AN9123293 & Not evaluated \\
\hline SCS 204 Predileto & EPAGRI & Selected from population MN 13337 introduced from CIAT & Not evaluated \\
\hline BRS Estilo & EMBRAPA & $\begin{array}{l}\text { It originated from junction EMP 250/4/A769///A429/ } \\
\text { XAN 252//V8025/PINTO VI114, carried out in } 1991 \text { at CIAT }\end{array}$ & Not evaluated \\
\hline BRS Notável & EMBRAPA & $\begin{array}{c}\text { Crossing lineages A769/4/A774///A429/XAN 252//V8025/ } \\
\text { G 4449//WAF 2/A55//GN31/XAN } 170\end{array}$ & Not evaluated \\
\hline CHIB 06 & EPAGRI & $\begin{array}{l}\text { Lineage obtained by the crossing between Ouro Branco } \\
\text { and Iraí }\end{array}$ & Not evaluated \\
\hline IPR Eldorado & IAC & Crossing from Carioca $99 \times$ G.N. Nebraska 1 Sel. $27 \times$ BAT 614 & Antixenosis (Silva et al. 2014) \\
\hline IPR Garça & IAPAR & Uninformed & Not evaluated \\
\hline lapar 81 & IAC & $\begin{array}{l}\text { A248/EMP117/4/Bat 93/2/Carioca Sel.99/ } \\
\text { G.N.Nebraska 1\#27/3/SelAroana }\end{array}$ & Antixenosis (Silva et al. 2014) \\
\hline IPR Quero-Quero & IAC & $\begin{array}{l}\text { Selection recurrent of genotypes BAT477, IAPAR 14, FT 84-29, } \\
\text { Jalo EEP, A252, A77, Ojo de Liebre, ESAL 645, Pintado, Carioca, } \\
\text { ESAL 645, P 85, P 103, H-4, AN910522, ESAL 624, Carioca MG }\end{array}$ & Not evaluated \\
\hline SCS 202 Guará & IAC & Acess Jabola Bag IAC $\times$ IAC Tybatã & Not evaluated \\
\hline Arcelina 4 & IAC & Jalo Itararé $\times$ IAC Carioca Eté & Antibiosis (Oriani and Lara 2000) \\
\hline CHIP 348 & EPAGRI & $\begin{array}{c}\text { Accession of the Epagri germplasm bank } \\
\text { ("Guarapuava black”), collected in the agricultural area of } \\
\text { São Carlos - SC (collected in 2002) }\end{array}$ & Not evaluated \\
\hline CHIP 300 & EPAGRI & $\begin{array}{l}\text { Accession of the Epagri germplasm bank, collected in } \\
\text { agricultural area of Chapeco - SC (collected in the 1980s) }\end{array}$ & Not evaluated \\
\hline Tybatã & IAC & Emp $81 \times$ H853-50-2 & Not evaluated \\
\hline IAC Carioca Eté & IAC & L933 × LM30630-12-2 & Not evaluated \\
\hline H96A102-1-1-1-52 & IAC & $\begin{array}{l}\text { (IAC Car. Aruã × G5686) } \times(\text { Xan 251. IAC Car. Akytã }) \\
\times(\text { IAC Car. Pyatã } \times \text { Mar 1) } \times \text { Pérola }\end{array}$ & Not evaluated \\
\hline Pérola & IAC & Selection in 'Aporé' & Susceptible (Silva et al. 2014) \\
\hline
\end{tabular}

\section{Colony of Bemisia tabaci biotype B}

The initial population of $B$. tabaci biotype B was obtained from IAC and maintained in a greenhouse $(2.5 \times 2.5 \times 2 \mathrm{~m})$ closed on the sides and on the ceiling with glass and an anti-aphid screen. For the maintenance of the insects, cabbage plants [Brassica oleracea (L.) var. acephala] were grown in plastic pots $(2.5 \mathrm{~L})$, and were irrigated and replaced as needed, in order to maintain their nutritional quality and also the vigor of populations of B. tabaci biotype B. This population was also characterized was characterized before the start of the research to confirm the biotype (Walsh et al. 1991; Simon et al. 1994; De Barro et al. 2003).

\section{Bioassays}

The biological performance of B. tabaci biotype B on the different genotypes was evaluated to verify the possible expression of antibiosis-resistance. Accordingly, the leaves (of the middle third) of the genotypes were individualized with cages made of "fabric voile" tissue $(15 \times 15 \mathrm{~cm})$, which were fixed to the petioles of the leaflets with a satin ribbon. With the aid of 
a buccal aspirator, 150 pairs of whiteflies were collected from the breeding stock and released inside the cages, where they remained for $24 \mathrm{~h}$, in order to obtain the eggs on the previously selected leaves. After this period, the cages were removed as well as the insects from the plants.

Under a stereoscopic microscope (40× magnification), the abaxial face of the leaflets was examined and an area containing 30 viable eggs per leaflet was delimited with Glitter (Acrilex, São Bernardo do Campo, SP, Brazil). Egg surplus was removed using cotton swabs (Cotonetes, Johnson \& Johnson, São Paulo, SP, Brazil) (Cruz et al. 2014). Three pots per genotype were used and each leaflet ( 2 per plant) represented one replicate, totaling six replicates per genotype $(\mathrm{n}=180)$, arranged under a randomized design.

The insects were daily observed to evaluate the following biological parameters: incubation period, duration of instars, total nymphal period, development period from egg to adult, mortality of nymphal instars, and nymphal viability.

\section{Statistical analysis}

The normality of residuals and homogeneity of variances were verified using the Shapiro-Wilk and Levene tests, respectively. When the assumptions were satisfied, the data were subjected to the analysis of variance using the $F$ test and, when there was a difference between the treatments, the means were compared using the Fisher LSD test ( $p>0.05$ ). For all analyses, the statistical package PROC MIXED-SAS, version 9.2 (SAS Institute 2008) was used.

\section{RESULTS}

The duration of the embryonic development of B. tabaci biotype B in the different genotypes of common bean varied from 8.40 to 10.57 days, with the highest mean values observed in the genotypes SCS Predileto, BRS Notável, SCS 202 Guará, CHIP 300, and Arcelina 4 (Table 2). The genotypes Tybatã, Pérola, IPR Eldorado, and IPR Garça had the shortest incubation periods.

The genotypes BRS Estilo (2.48 days), Pérola (2.23 days), and Tybatã (2.20 days) differed from most of the genotypes (Table 2). For the second instar, the longest duration was observed in nymphs confined in CHIP 300 and CHIB 06 (7.54 and 6.15 days, respectively), differing from the other genotypes (Table 2). Genotypes Pérola (2.62 days) and Tybatã (3.03 days) provided the shortest periods for the second instar of the whitefly. The highest durations for the third instar were verified in genotypes CHIP 348 (10.76 days), CHIP 300 (10.57 days), and IPR Eldorado (10.21 days), differing from most of the evaluated genotypes (Table 2). Pérola (4.23 days) and CHIB 06 (5.12 days) had the lowest average lengths for the third instar nymphs (Table 2). In the fourth instar, the nymphs confined to the genotypes CHIP 300, H96A102-1-1-1-52, Pérola, Arcelina 4, and IPR Quero-Quero presented a significant prolongation of the duration (between 6.15 and 6.80 days), differing from most of the evaluated genotypes, mainly CHIB 06, SCS 202-Guará, SCS 204 Predileto, and CHIP 348 (Table 2).

There was a large variation in the total nymphal period of B. tabaci biotype B, with emphasis on the CHIP 300 genotype (24.91 days), which extended the nymphal period by approximately nine days in comparison to the standard susceptible genotype (Pérola) (Table 2), differing from all other genotypes. In CHIP 348 (21.84 days) and H96A102-1-1-1-52 (21.60 days), intermediate prolongation was observed compared with the standard genotype, differing from most genotypes (Table 2). The largest prolongation of the egg-adult period was observed in the CHIP 300 genotype (34.22 days), which differed from all other genotypes (Fig. 1). In turn, the susceptible standard genotype (Pérola) had the shortest egg-adult developmental period (24.36 days) (Fig. 1).

As for the four nymphal stages of $B$. tabaci biotype $\mathrm{B}$, no significant differences in mortality were observed among the genotypes for the first and third instars of the whitefly (Fig. 2). However, there was a marked mortality of second-instar nymphs, especially CHIP 300 (38.89\%), H96A102-1-1-1-52 (30.00\%), BRS Estilo (26.11\%), and BRS Esplendor (23.89\%), which differed from most of the genotypes evaluated (Fig. 2 b). In the fourth instar, high mortality rates were observed in 
IPR Eldorado (26.11\%), BRS Estilo (22.22\%), Tybatã (19.44\%), and IPR Garça genotypes (19.44\%), differing from most of the genotypes (Fig. 2 d).

Table 2. Means ( \pm SE) for incubation period, nymphal instar, and nymphal period of Bemisia tabaci biotype B in 17 common bean genotypes, in a greenhouse trial.

\begin{tabular}{|c|c|c|c|c|c|c|}
\hline \multirow{2}{*}{ Genotype } & \multicolumn{6}{|c|}{ Duration (days) } \\
\hline & Incubation $^{1}$ & 1st instar ${ }^{1}$ & 2nd instar ${ }^{1}$ & $3 r d$ instar $^{1}$ & 4th instar ${ }^{1}$ & Nymphal period $^{1}$ \\
\hline $\begin{array}{l}\text { SCS } 204 \\
\text { Predileto }\end{array}$ & $10.57 \pm 0.25 a$ & $1.84 \pm 0.13 \mathrm{cde}$ & $3.40 \pm 0.09 \mathrm{hg}$ & $9.00 \pm 0.88 \mathrm{cdef}$ & $5.04 \pm 0.28$ ef & $19.26 \pm 0.71$ ef \\
\hline BRS Notável & $10.35 \pm 0.17 a b$ & $1.78 \pm 0.08 \mathrm{ed}$ & $4.18 \pm 0.24$ cdef & $9.18 \pm 0.25$ bcde & $5.63 \pm 0.30 \mathrm{cde}$ & $20.50 \pm 0.70$ cde \\
\hline SCS 202Guará & $10.11 \pm 0.20 \mathrm{abc}$ & $2.00 \pm 0.06 \mathrm{bcd}$ & $3.58 \pm 0.14 \mathrm{fgh}$ & $9.77 \pm 0.26 a b c$ & $4.95 \pm 0.02$ ef & $20.01 \pm 0.33 \mathrm{ed}$ \\
\hline CHIP 300 & $10.05 \pm 0.21 \mathrm{abc}$ & $1.66 \pm 0.09 \mathrm{e}$ & $7.54 \pm 0.39 a$ & $10.57 \pm 0.30 a$ & $6.80 \pm 0.35 a$ & $24.91 \pm 0.46 a$ \\
\hline Arcelina4 & $9.96 \pm 0.17 \mathrm{abc}$ & $1.84 \pm 0.13 \mathrm{cde}$ & $4.44 \pm 0.25 \mathrm{~cd}$ & $7.72 \pm 0.67 \mathrm{~g}$ & $6.17 \pm 0.23 a b c$ & $20.27 \pm 0.74 \mathrm{ed}$ \\
\hline BRS Esplendor & $9.80 \pm 0.17 b c$ & $1.84 \pm 0.18 \mathrm{cde}$ & $4.23 \pm 0.31$ cdef & $8.33 \pm 0.54$ efg & $5.63 \pm 0.36 \mathrm{cde}$ & $19.94 \pm 0.21 \mathrm{ed}$ \\
\hline lapar 81 & $9.72 \pm 0.05 \mathrm{bcd}$ & $2.14 \pm 0.05 b c$ & $4.01 \pm 0.03 \mathrm{defg}$ & $8.58 \pm 0.07 \mathrm{defg}$ & $5.25 \pm 0.08 \mathrm{de}$ & $19.74 \pm 0.07$ def \\
\hline CHIP 348 & $9.72 \pm 0.24 \mathrm{bcd}$ & $1.87 \pm 0.04 \mathrm{cde}$ & $4.19 \pm 0.12$ cdef & $10.76 \pm 0.41 a$ & $5.11 \pm 0.30 \mathrm{e}$ & $21.84 \pm 0.30 \mathrm{~b}$ \\
\hline IAC Carioca Eté & $9.69 \pm 0.22 b c$ & $1.65 \pm 0.08 \mathrm{e}$ & $4.78 \pm 0.29 c$ & $8.57 \pm 0.10$ defg & $5.69 \pm 0.22 \mathrm{bcde}$ & $20.18 \pm 0.13 \mathrm{de}$ \\
\hline $\begin{array}{c}\text { IPR } \\
\text { Quero-Quero }\end{array}$ & $9.62 \pm 0.19 \mathrm{~cd}$ & $1.97 \pm 0.07 \mathrm{bcd}$ & $3.91 \pm 0.25$ defg & $9.29 \pm 0.32 \mathrm{bcde}$ & $6.15 \pm 0.32 a b c$ & $20.86 \pm 0.39 \mathrm{bcd}$ \\
\hline H96A102-1-1-1-52 & $9.62 \pm 0.30 \mathrm{~cd}$ & $1.89 \pm 0.07 \mathrm{cde}$ & $3.79 \pm 0.26$ defg & $9.65 \pm 0.34 \mathrm{abcd}$ & $6.74 \pm 0.40 a$ & $21.60 \pm 0.46 b c$ \\
\hline CHIB 06 & $9.53 \pm 0.16 \mathrm{cde}$ & $2.05 \pm 0.05 \mathrm{bcd}$ & $6.15 \pm 0.35 b$ & $5.12 \pm 0.07 \mathrm{~h}$ & $4.27 \pm 0.04 f$ & $18.53 \pm 0.17 f$ \\
\hline BRS Estilo & $9.07 \pm 0.43$ def & $2.48 \pm 0.14 a$ & $4.27 \pm 0.40$ cde & $7.99 \pm 0.78 \mathrm{fg}$ & $5.97 \pm 0.64 \mathrm{abcd}$ & $20.58 \pm 1.00$ bcde \\
\hline IPR Garça & $8.92 \pm 0.33$ efg & $2.14 \pm 0.25 b c$ & $4.11 \pm 0.17$ cdef & $8.68 \pm 0.30$ cdefg & $5.35 \pm 0.19 \mathrm{de}$ & $20.14 \pm 0.26 \mathrm{de}$ \\
\hline IPR Eldorado & $8.86 \pm 0.36 \mathrm{fg}$ & $2.04 \pm 0.14 \mathrm{bcd}$ & $3.71 \pm 0.08 \mathrm{efg}$ & $10.21 \pm 0.22 \mathrm{ab}$ & $5.63 \pm 0.10 f$ & $20.51 \pm 0.25 \mathrm{cde}$ \\
\hline Pérola & $8.66 \pm 0.17 \mathrm{fg}$ & $2.23 \pm 0.00 \mathrm{ab}$ & $2.62 \pm 0.01 \mathrm{i}$ & $4.23 \pm 0.02 \mathrm{~h}$ & $6.44 \pm 0.02 a b$ & $15.73 \pm 0.02 \mathrm{~g}$ \\
\hline Tybatã & $8.40 \pm 0.04 \mathrm{~g}$ & $2.20 \pm 0.05 a b$ & $3.03 \pm 0.03 \mathrm{hi}$ & $8.87 \pm 0.04$ cdefg & $5.63 \pm 0.07 \mathrm{cde}$ & $19.52 \pm 0.07$ ef \\
\hline $\mathrm{F}$ & 6.61 & 3.88 & 22.35 & 16.56 & 7.31 & 16.70 \\
\hline$d f$ & 16.81 & 16.81 & 16.81 & 16.81 & 16.81 & 16.81 \\
\hline$p$ value & $<0.0001$ & 0.0001 & 0.0001 & 0.0001 & 0.0001 & 0.0001 \\
\hline
\end{tabular}

${ }^{1}$ Means followed by the same letter in the column do not differ statistically from one another by the Fisher LSD Test ( $\left.p>0.05\right)$.

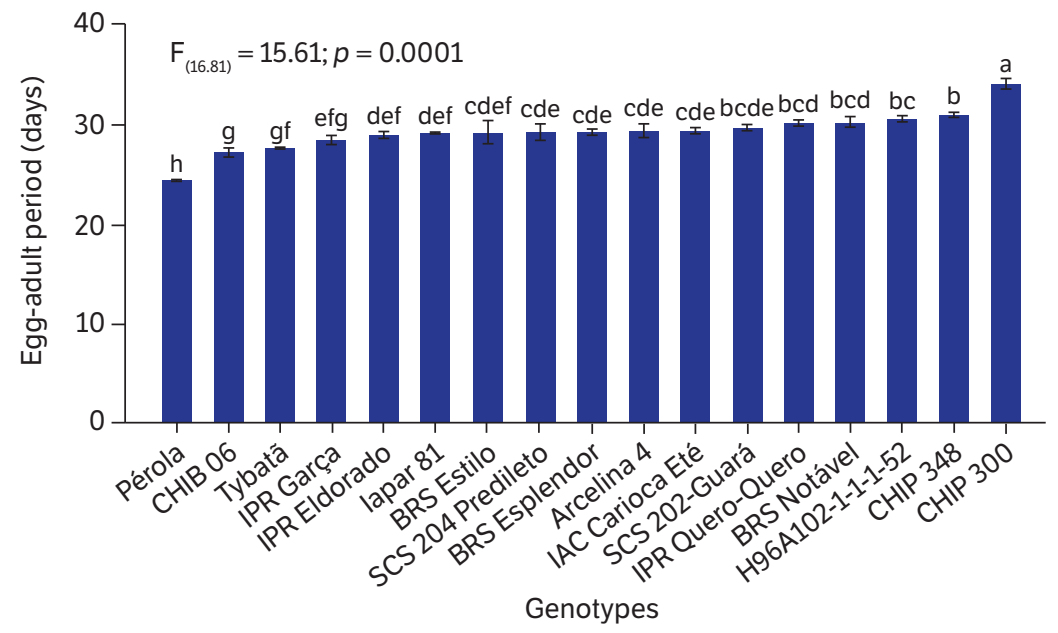

Figure 1. Means ( \pm SE) of the development period from egg to adult (in days) of Bemisia tabaci biotype B in 17 common bean genotypes, in a greenhouse trial. Means followed by the same letter in the column do not differ statistically from each other by the Fisher LSD Test $(p>0.05)$. 
The highest nymphal viability (85\%) was observed in the Pérola genotype, which differed from the other evaluated materials (Fig. 3). The genotypes CHIB 06 (29.13\%), Arcelina 4 (29.44\%), CHIP 300 (30\%), BRS Estilo (34.16\%), and IPR Eldorado (35.55\%) showed the lowest viability indexes for the immature phase of the whitefly (Fig. 3 ).
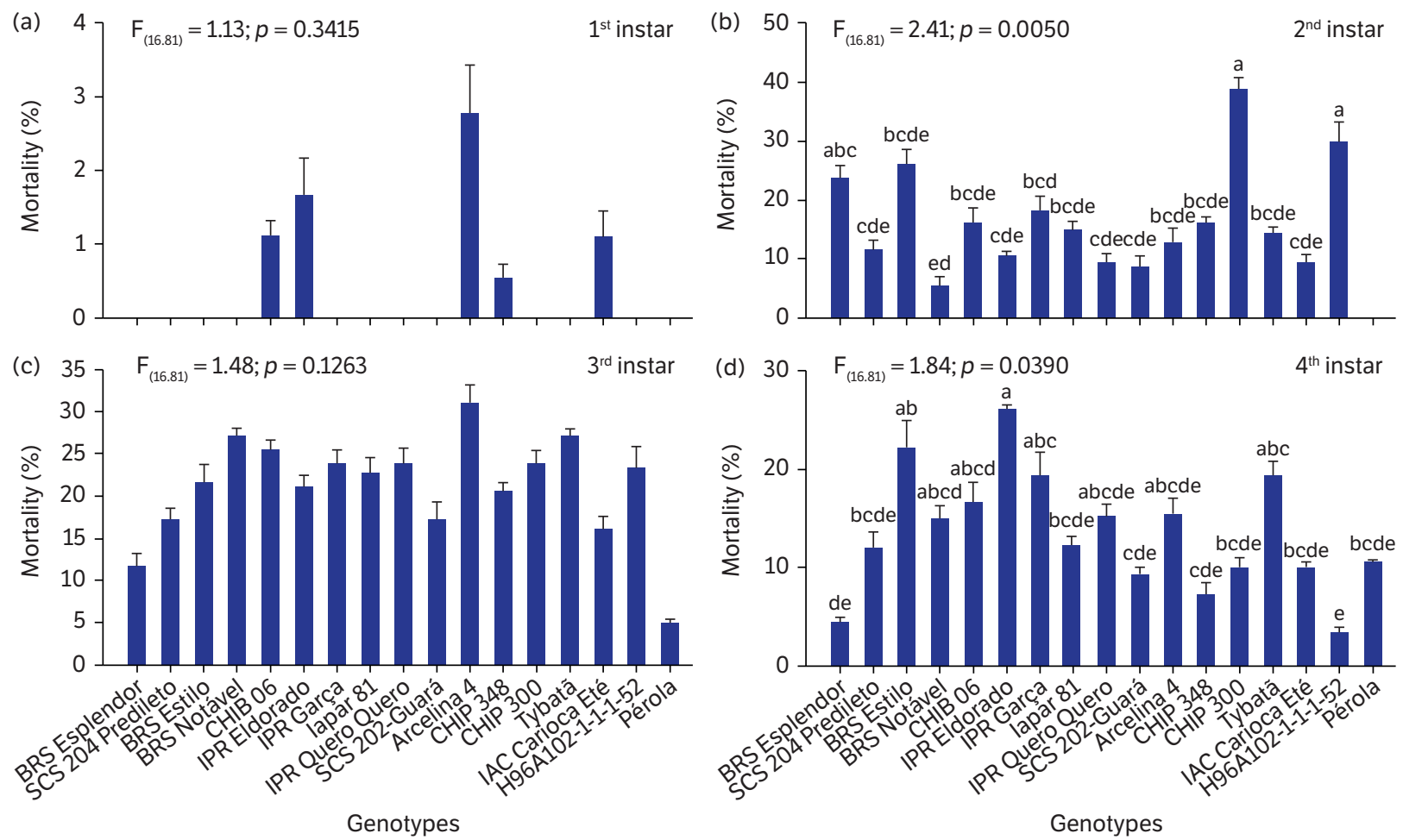

Figure 2. Means ( \pm SE) of mortality per nymphal instar of Bemisia tabaci biotype B when confined in 17 common bean genotypes. Means followed by the same letter in the column do not differ statistically from each other by the Fisher LSD Test $(p>0.05)$.

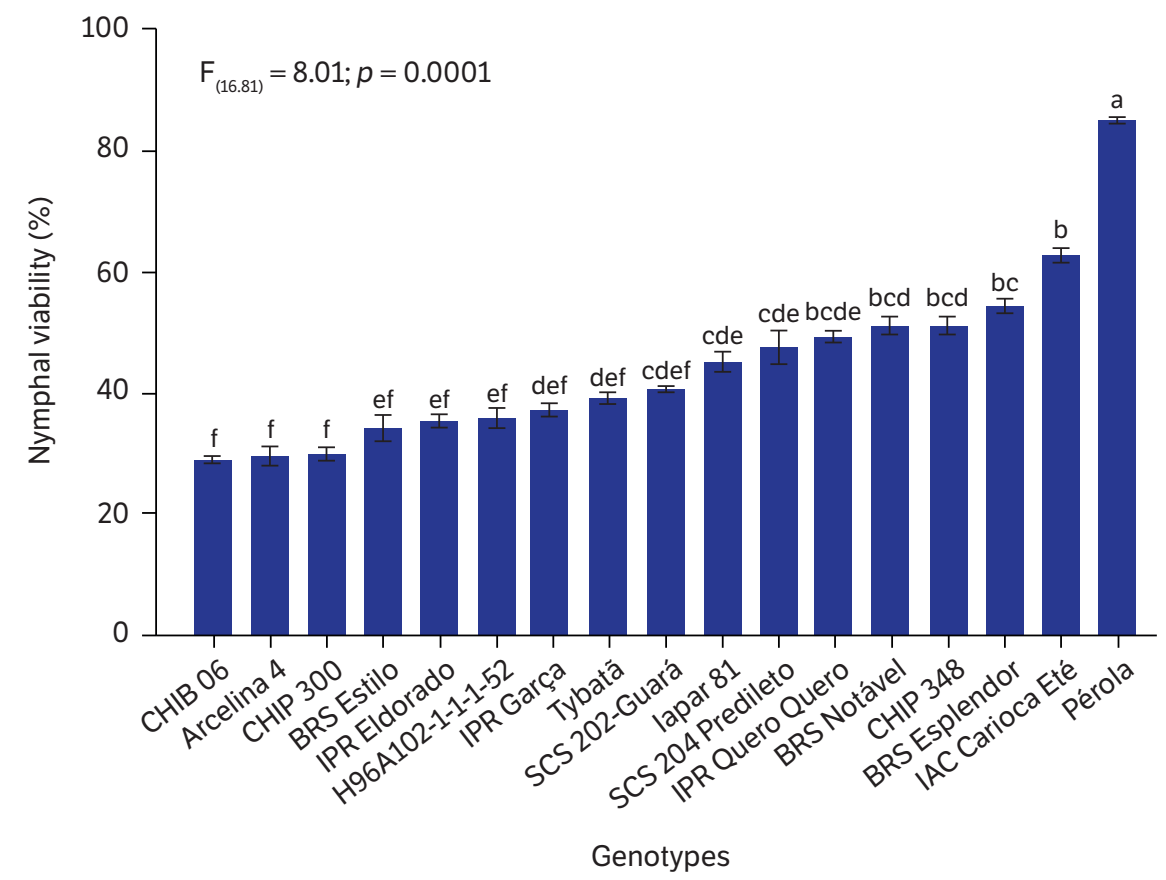

Figure 3. Means ( \pm SE) of the percentage of nymphal viability of Bemisia tabaci biotype $B$ in 17 common bean genotypes, in greenhouse. Means followed by the same letter in the column do not differ statistically from each other by the Fisher LSD Test $(p>0.05)$. 


\section{DISCUSSION}

Reportedly, phytophagous insects consume large amounts of tissues and suck sap of various plant structures, despite the immense variation in the amount of nutrients, as well as the existence of innumerable physical and chemical barriers developed by plants to inhibit or prevent the attack (Bernays and Chapman 1994). However, the acceptance or rejection of host plants by insects depends on defense responses used by plants. Thus, successful colonization of pest insects depends on the presence or absence of various secondary metabolites associated with the possible host plant (Douglas 2018).

In general, insects attempting to colonize plants with antibiosis resistance, that is, plants with the capacity to affect their biology, present reductions in size and weight, diverse deformities, and prolongations in the lifecycle phases and, consequently, high mortality rates (Painter 1951). In the present study, the incubation period of the whitefly eggs in some of the evaluated genotypes was observed; in similar studies, the incubation period of the eggs of B. tabaci biotype B in bean genotypes ranged from 8.00 to 11.00 days (Torres et al. 2012; Peixoto and Boiça Júnior 2014). In the present study, the Tybatã and Pérola genotypes had the shortest incubation periods ( 8.40 and 8.66 days, respectively), consistent with the study by Peixoto and Boiça Júnior (2014), who observed that the incubation periods for these two genotypes ranged from 8.03 to 8.59 days. The change in the incubation period may be associated with biochemical causes related to common bean genotypes, or even to environmental factors (Smith 2005). Some authors suggest that the pedicel, besides fixing eggs on the plants, works absorbing water and even other compounds present on the plant, interfering on the whitefly embryonic development on common bean (Gameel 1974, Byrne and Bellows Junior 1991). In another study with B. tabaci biotype B in common bean, authors suggest that prolonged incubation periods might be influenced by low temperatures and humidity (Oriani and Lara 2000). However, in the present study these factors have not been evaluated and may be considered in further studies.

Genotype CHIP 300 (24.91 days) prolonged the nymphal period of the whitefly by approximately nine days compared with the susceptibility-standard genotype, Pérola (15.73 days). Such an extension may be associated with the presence of morphological factors, such as waxiness and/or trichomes (Glas et al. 2012), or even by chemical factors associated with resistance (Bernays and Chapman 1994; Smith 2005; Douglas 2018). The high prolongation of the instars from insect pests in the genotypes CHIP 300, CHIP 348, and H96A102-1-1-1-52 suggests the occurrence of antibiosis and/or antixenosis type resistance in the respective genotypes (Painter 1951).

The largest prolongation from egg to adult was observed in the genotype CHIP 300 (34.22 days), which required approximately 10 days more to complete the cycle compared with the susceptible Pérola genotype ( 24.36 days). This may be due to a lower nutritional adequacy or the presence of antibiotic factors in this genotype, which are aspects that must be better investigated in future studies. Based on the available literature, the duration of the egg to adult period varies between bean genotypes, and there are reports of periods between 16.20 and 41.00 days (Oriani and Lara 2000; Torres et al. 2012). Some references reported a large variation in the development period of the whitefly on cowpea genotypes (Cruz et al. 2014), cabbage (Villas Bôas et al. 1997), cotton (Prado et al. 2015), soybean (Cruz and Baldin 2016), tomato (Baldin et al. 2005), squash varieties (Baldin and Benduzzi 2010), melon (Baldin et al. 2012) and, more recently, peppers, where a duration of 30.25 days was observed (Pantoja et al. 2018), similar to the present study.

The genotypes CHIB 06 (29.13\%), Arcelina 4 (29.44\%), CHIP 300 (30.00\%), BRS Estilo (34.16\%), and IPR Eldorado (35.55\%) caused low nymphal viability, also suggesting the expression of antibiosis resistance. However, some plants have combinations of chemical and morphological resistance factors with extremely inhibitory effects on insect-pest performance, making it difficult to isolate the causes related to antibiosis and/or antixenosis, as discussed by other authors (Panda and Khush 1995; Smith and Clement 2012).

In a study with the genotypes Iapar 81 and IPR Eldorado, high nymphal viability of whitefly was verified, with rates of 88.70 and $69.30 \%$, respectively (Silva et al. 2014), in contrast to the present study, where viability in the two genotypes did not exceed $45 \%$. These divergences are probably associated with the methodological or climatic differences (uninformed temperature) employed in the study of these authors. Other studies reporting low rates of nymphal viability of whitefly to antibiosis were also described in different hosts, such as cowpea (45.50 to $89.10 \%$ ) (Cruz et al. 2014), soybean (68.60\% to 89,60\%) (Cruz et al. 2016), zucchini (36.10 to $100 \%$ ) (Baldin and Beneduzzi 2010), and peppers (0 to 25\%) (Pantoja et al. 2018). As they negatively affect the performance 
of the insect's immature stages, the plants with antibiosis commonly cause high rates of nymphal or larval mortality, compromising the emergence of adults (Painter 1951; Panda and Khush 1995; Smith 2005), as verified in some genotypes in the present study.

The genotypes that demonstrated high levels of mortality in the different nymphal stages were CHIP 300, BRS Estilo, Arcelina 4, IPR Garça, and Tybatã. The mortality increased from the second instar, probably owing to increased insect feeding activity. Although the five genotypes showed a significant deleterious effect on the whitefly nymphs, it was observed in the CHIP 300 genotype that the effects were more intense, with common findings of individuals with deformities (Fig. 4 b), and difficulties in the molting processes (Fig. $4 \mathrm{~d}$ ) and adult emergence (Fig. 4 f), compared with the same-stage individuals confined to the susceptible Pérola genotype (Fig. 4 a, c, e). The images (Fig. 4 b, d, f) indicate antibiosis as a mechanism of resistance in these genotypes. However, new studies are required to further elucidate the possible role of chemical resistance factors such as enzyme inhibitors or antibiotic compounds (alkaloids, flavonoids, and terpenoids) (Kubo and Hanke 1986) involved in the resistance of these materials.

Although the studies that characterized the expression of antibiosis in bean genotypes to whitefly are scarce, some authors have suggested that secondary compounds could be responsible for the negative effects on the biology of $B$. tabaci biotype $B$, as seeing in a study carried out with the Arcelina bean genotype 4 cultivated during the dry season, the nymphal mortality index of $80 \%$ of B. tabaci biotype B was verified (Oriani and Lara 2000). In the study, the authors suggested the presence of the arcelin protein as a possible resistance factor in the tested genotype, which may be responsible for the high mortality of insect nymphs. In soybean crop, it has been suggested that flavonoid-bearing genotypes may also negatively affect the biology of the whitefly (Vieira et al. 2016). In cotton genotypes, the presence of higher levels of gossypol in certain materials was negatively correlated with the biology of B. tabaci biotype B (Guo et al. 2013).
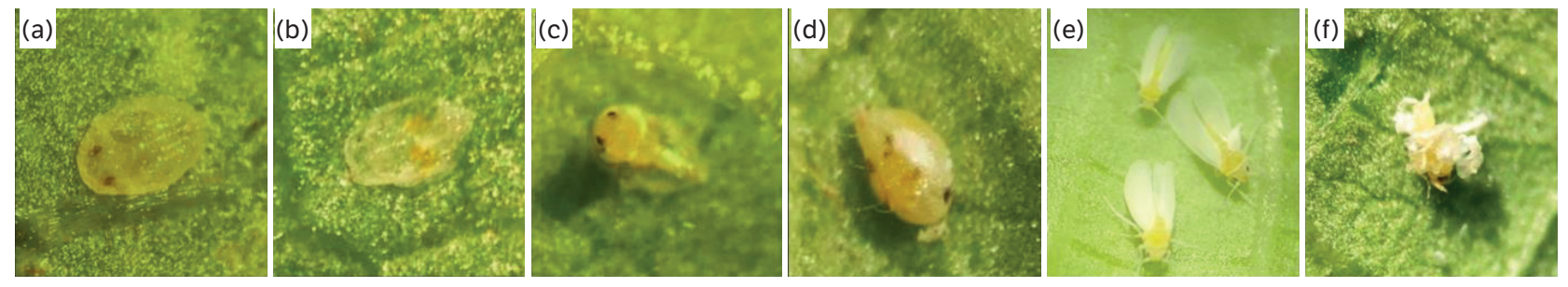

Figure 4. Different stages of development of Bemisia tabaci biotype B observed on leaflets of the susceptible bean genotypes Pérola (a, $\mathrm{c}$ and e) and of the CHIP 300 antibiotic resistant (b, $d$ and f).

\section{CONCLUSION}

Considering all the results obtained in the biological performance tests of $B$. tabaci biotype $B$ in common bean genotypes, it was verified that the CHIP 300 genotype caused a greater prolongation of the egg to adult period of B. tabaci biotype B, indicating the expression of antibiosis and/or antixenosis. In addition, CHIP 300 and the genotypes BRS Estilo, Arcelina 4, IPR Garça, Tybatã, IPR Eldorado, H96A102-1-1-1-52, and CHIB 06 negatively affected the development (viability) of the whitefly, indicating high levels of resistance through antibiosis and/or antixenosis. However, the resistance factors associated with these materials must be better investigated by characterizing the biochemical composition of these genotypes. Thus, these genotypes may constitute important sources of resistance to $B$. tabaci biotype B for breeding programs to obtain resistant cultivars.

\section{FUNDING}

Coordenação de Aperfeiçoamento de Pessoal de Nível Superior

[https://doi.org/10.13039/501100002322]

Grant \# Finance Code 001 
CNPq for the Research Productivity

[https://doi.org/10.13039/501100003593]

Grant \# 305649/2013-2

\section{AUTHORS' CONTRIBUTION}

Conceptualization, Santos T. L. B. and Baldin E. L. L.; Methodology, Santos T. L. B., Silva I. F., Bueno N. M. and Souza C. M.; Investigation, Santos T. L. B.; Writing - Original Draft, Santos T. L. B.; Writing - Review and Editing, Ribeiro L. P., Silva I. F. and Bueno N. M.; Supervision, Baldin E. L. L.

\section{REFERENCES}

Alford, A. and Krupke, C. H. (2017). Translocation of the neonicotinoid seed treatment clothianidin in maize. PLOS One, 12 , e0173836. https://doi.org/10.1371/journal.pone.0173836

Alon, M., Alon, F., Nauen, R. and Morin. (2008). Organophosphates' resistance in the B-biotype of Bemisia tabaci (Hemiptera: Aleyrodidae) is associated with a point mutation in an ace1-type acetylcholinesterase and over expression of carboxylesterase. Insect Biochemistry and Molecular Biology, 38, 940-949. https://doi.org/10.1016/j.ib.2008.07.007

Aragão, F. J. and Faria, J. C. (2009). First transgenic geminivirus-resistant plant in the field. Nature Biotechnology. 27, 1086-1088. https:// doi.org/10.1038/nbt1209-1086

Baldin, E. L. L. and Beneduzzi, R. A. (2010). Characterization of antibiosis and antixenosis to the whitefly silverleaf Bemisia tabaci B biotype (Hemiptera: Aleyrodidae) in several squash varieties. Journal of Pest Science, 83, 223-229. https://doi.org/10.1007/s10340-010-0289-2

Baldin, E. L. L., Silva, J. P. G. F. and Pannuti, L. E. R. (2012). Resistance of melon cultivars to Bemisia tabaci biotype B. Horticultura Brasileira, 30, 600-606. https://doi.org/10.1590/S0102-05362012000400007

Baldin, E. L. L., Vendramim, J. D. and Lourenção, A. L. (2005). Resistance of tomato genotypes to the whitefly Bemisia tabaci (Gennadius) biotype B (Hemiptera: Aleyrodidae). Neotropical Entomology, 34, 435-441. https://doi.org/10.1590/S1519-566X2005000300012

Bernays, E. A. and Chapman, R. F. (1994). Host-plant selection by phytophagous insects. New York: Springer.

Byrne, D. N. and Bellows Junior, T. S. (1991). Whitefly biology. Annual Review Entomology, 36, 431-457. https://doi.org/10.1146/annurev. en.36.010191.002243

Boykin, L. M., Kinene, T., Wainaina, J. M., Savill, A., Seal, S., Mugerwa, H., Macfadyen, S., Tay, W. T., De Barro, P., Kubatko, L., Alicai, T., Omongo, C. A., Tairo, F., Ndunguru, J. and Sseruwagi, P. (2018). Review and guide to a future naming system of African Bemisia tabaci species. Systematic Entomology, 43, 427-433. https://doi.org/10.1111/syen.12294

Carvalho, J. J., Saad, J. C. C., Bastos, A. V. S., Naves, S. S., Soares, F. A. L. and Vidal, V. M. (2014). Teor e acúmulo de nutrientes em grãos de feijão comum em semeadura direta, sob déficit hídrico. Irriga, 1, s1, 104-117.

Costa, B. H. G., Resende, M. L. V., Monteiro, A. C. A., Ribeiro Júnior, P. M., Botelho, D. M. S. and Silva, B. M. (2018). Potassium phosphites in the protection of common bean plants against anthracnose and biochemical defence responses. Journal of Phytopathology, 166, 2 , 95-102. https://doi.org/10.1111/jph.12665

Cruz, P. L., Baldin, E. L. L. and Castro, M. J. P. (2014). Characterization of antibiosis to the silverleaf whitefly Bemisia tabaci biotype B (Hemiptera: Aleyrodidae) in cowpea entries. Journal of Pest Science, 87, 639-645. https://doi.org/10.1007/s10340-014-0612-4 
Cruz, P. L. and Baldin, E. L. L. (2016). Performance of Bemisia tabaci biotype B on soybean genotypes. Neotropical Entomology, 46, 210215. https://doi.org/10.1007/s13744-016-0445-3

Desneux, N., Deucourtye, A. and Delpuech, J. M. (2007). The subletal effects of pesticides on beneficial arthropods. Annual Review of Entomology, 52, 81-106. https://doi.org/10.1146/annurev.ento.52.110405.091440

De Barro, P. J., Liu, S.-S., Boykin, L. M. and Dinsdale, A. B. (2011). Bemisia tabaci: a statement of species status. Annual Review of Entomology, 56, 1-19. https://doi.org/10.1146/annurev-ento-112408-085504

De Barro, P. J., Scott, K. D., Graham, G. C., Lange, C. L. and Schutze, M. K. (2003). Isolation and characterization of microsatellite loci in Bemisia tabaci. Molecular Ecology Notes, 3, 40-43. https://doi.org/10.1046/j.1471-8286.2003.00344.x

Dinsdale, A., Cook, L., Riginos, C., Buckley, Y. M., De Barro, P. (2010). Refined global analysis of Bemisia tabaci (Gennadius) (Hemiptera: Sternorrhyncha: Aleyrodidea): mitochondrial cytochrome oxidase 1 to identify species level genetic boundaries. Annals of the Entomological Society of America, 103, 196-208.

Douglas, A. E. (2018). Strategies for enhanced crop resistance to insect pests. Annual Review of Plant Biology, 69, 637-660. https://doi. org/10.1146/annurev-arplant-042817-040248

Fancelli, A. L. (2010). Feijão - Tópicos de Nutrição e Adubação. Piracicaba: ESALQ. (p. 1-24).

[FAO] Food and Agriculture Organization of the United Nations (2015). [Accessed Dec. 17,2017]. Available at: http://www.fao.org/3/a-bb029e

Furlan, L. and Kreutzweiser, D. (2015). Alternatives to neonicotinoid insecticides for pest control: case studies in agriculture and forestry. Environmental Science and Pollution Research, 22, 135-147. https://doi.org/10.1007/s11356-014-3628-7

Garrido-Ramirez, E. R., Sudashana, M. R. and Gilbertson, R. L. (2000). Bean golden yellow mosaic virus from Chiapas, Mexico: characterization, pseudorecombination with other bean-infecting geminiviruses and germ plasm screening. Phytopathology, 90, 12241232. https://doi.org/10.1094/PHYTO.2000.90.11.1224

Gameel, O. I. (1974). Some aspects of the mating and oviposition behavior of the cotton whitefly Bemisia tabaci (Genn.). Revue de Zoologie et de Botanique Africaine, 88, 784-788.

Glas, J. J., Schimmel, B. C. J., Alba, J. M., Escobar-Bravo, R., Schuurink, R. C. and Kant, M. R. (2012). Plant glandular trichomes as targets for breeding or engineering of resistance to herbivores. International Journal of Molecular Sciences, 13, 17070-17103. https://doi. org/10.3390/ijms131217077

Guo, J.-Y., Wu, G. and Wan, F.-H. (2013). Effects of high-gossypol cotton on the development and reproduction of Bemisia tabaci (Hemiptera: Aleyrodidae) MEAM1 cryptic species. Journal of Economic Entomology, 106, 1379-1385. http://doi.org/10.1603/EC12401

Houndete, T. A., Kétoh, G. K., Hema, O. S. A., Brévault, T., Glitho, I. A. and Martin, T. (2010). Insecticide resistance in field populations of Bemisia tabaci (Hemiptera: Aleyrodidae) in West Africa. Pest Management Science, 66, 1181-1185. https://doi.org/10.1002/ps.2008

Horowitz, A. R., Kontsedalov, S., Denholm, I. and Ishaaya, I. (2002). Dynamics of insecticide resistance in Bemisia tabaci: a case study with the insect growth regulator pyriproxyfen. Pest Management Science, 58, 1096-1100. https://doi.org/10.1002/ps.545

Kogan, M. (1998). Integrated pest management: historical perspectives and contemporary developments. Annual Review of Entomology, 43, 243-270. https://doi.org/10.1146/annurev.ento.43.1.243

Kubo, I. and Hanke, F. G. (1986). Chemical methods for isolating and identifying phytochemicals biologically active in insects. In Miller, J. R. and Miller, T. A. (Eds.). Insects-plant interactions (p.21-153). New York: Springer.

Lara, F. M. (1991). Princípios de resistência de plantas a insetos. 2. ed. São Paulo: Ícone. 
Ma, W., Li, X., Dennehy, T. J., Lei, C., Wang, M., Degain, B. A. and Nichols, R. L. (2010). Pyriproxyfen resistance of Bemisia tabaci (Homoptera: Aleyrodidae) Biotype B: metabolic mechanism. Journal of Economic Entomology, 103, 158-165. https://doi.org/10.1603/EC09122

Moraes, S. R. G., Pozza, E. A., Alves, E., Pozza, A. A. A., Carvalho, J. G., Lima, P. H. and Botelho, A. O. (2006). Efeito de fontes de silício na incidência e na severidade da antracnose do feijoeiro. Fitopatologia Brasileira, 31, 69-75. https://doi.org/10.1590/S0100-41582006000100012

Musa, P. D. and Ren, S.-X. (2005). Development and reproduction of Bemisia tabaci (Homoptera: Aleyrodidae) on three bean species. Insect Science, 12, 25-30. https://doi.org/10.1111/j.1672-9609.2005.00004.x

Naranjo, S. E. and Legg, J. P. (2010). Biology and ecology of Bemisia tabaci. In Stansly, P. A. and Naranjo, S. E. (Eds.). Bemisia: bionomics and management of a global pest (p. 105-107). Dordrecht: Springer.

Oriani, M. A. G. and Lara, F. M. (2000). Antibiosis effects of wild bean lines containing arcelin on Bemisia tabaci (Genn.) biotype B (Homoptera: Aleyrodidae). Anais da Sociedade Entomológica Brasileira, 29, 573-582. https://doi.org/10.1590/S0301-80592000000300020

Oriani, M. A. G., Vendramim, J. D. and Brunherotto, R. (2005). Influence of trichomes on oviposition al preference of Bemisia tabaci (Genn.) biotype B (Hemiptera: Aleyrodidae) for bean genotypes. Neotropical Entomology, 34, 97-103. https://doi.org/10.1590/ S1519-566X2005000100014

Painter, R. H. (1951). Insect resistance in crop plants. New York: McMillan.

Panda, N. and Khush, G. S. (1995). Host plant resistance to insects. Oxon: CAB International.

Pantoja, K. F. C., Rocha, K. C. G., Melo, A. M. T., Marubayashi, J. M., Baldin, E. L. L., Bentivenha, J. P. F., Gioria, R., Kobori, R. F., Pavan, M. A. and Krause-Sakate, R. (2018). Identification of Capsicum accessions tolerant to Tomato severe rugose virus and resistant to Bemisia tabaci Middle East-Asia Minor 1 (MEAM1). Tropical Plant Pathology, 43, 138-145. https://doi.org/10.1007/s40858-018-0212-6

Peixoto, M. L. and Boiça Júnior, A. L. (2014). Antibiose e não preferência para oviposição de Bemisia tabaci (Genn.) biótipo B (Hemiptera: Aleyrodidae) em genótipos de feijoeiro comum. Arquivos do Instituto Biológico, 81, 134-139. https://doi.org/10.1590/1808-1657000992012

Pedigo, L. P. (2002). Entomology and pest management. Singapore: Pearson Education.

Perkins, J. H. (1982). Insects, experts and the insecticide crisis: the quest for new pest management strategies. New York: Plenum.

Prado, J. C., Peñaflor, M. F. G. V., Cia, E., Vieira, S. S., Silva, K. I., Carlini-Garcia, L. A. and Lourenção, A. L. (2015). Resistance of cotton genotypes with different leaf colour and trichome density to Bemisia tabaci biotype B. Journal of Applied Entomology, 140, 405-413. https://doi.org/10.1111/jen.12274

SAS Institute. (2009). PROC user’s manual, version 9.2. Cary: SAS Institute.

Santos, T. L. B. (2018). Caracterização de antixenose e antibiose de genótipos de feijoeiro (Phaseolus vulgaris L.) sobre Bemisia tabaci (Genn.) biótipo B (Hemiptera: Aleyrodidae). (Dissertação de mestrado). Universidade Estadual Paulista, Faculdade de Ciências Agronômica, Departamento de Proteção Vegetal, Botucatu, Brasil.

Silva, A. G., Boiça Júnior, A. L., Farias, P. R. S., Rodrigues, N. E. L., Souza, B. H. S., Bottega, D. B. and Chiorato, A. F. (2014). Non-preference for oviposition and antibiosis in bean cultivars to Bemisia tabaci biotype B (Hemiptera: Aleyrodidae). Revista Colombiana de Entomologia, 40, 7-14.

Smith, C. M. (2005). Plant resistance to arthropods: molecular and conventional approaches. New York: Springer.

Smith, C. M. and Clement, S. L. (2012). Molecular bases of plant resistance to arthropods. Annual Review of Entomology, 57, $309-328$. https://doi.org/10.1146/annurev-ento-120710-100642 
Simon, C., Frati, F., Beckenbach, A., Crespi, B., Liu, H. and Flook, P. (1994). Evolution, weighting and phylogenetic utility of mitochondrial gene-sequences and a compilation of conserved polymerase chain-reaction primers. Annals of the Entomological Society of America, 87, 651-701. https://doi.org/10.1093/aesa/87.6.651

Tay, W. T., Elfekih, S., Polaszek, A., Court, L. N., Evans, G. A., Gordon, K. H. J. and De Barro, P. J. (2017). Novel molecular approach to define pest species status and tritrophic interactions from historical Bemisia specimens. Scientific Reports, 7, 1-13. https://doi.org/10.1038/ s41598-017-00528-7

Torres, L. C., Souza, B., Lourenção, A. L., Costa, M. B., Amaral, B. B., Carbonell, S. A. M., Chiorato, A. F. and Tanque, R. L. (2012). Resistência de genótipos de feijoeiro a Bemisia tabaci biótipo B. Bragantia, 71, 346-354. https://doi.org/10.1590/S0006-87052012005000031

Valle, G. E., Lourenção, A. L. and Pinheiro, J. B. (2012). Adult attractiveness and oviposition preference of Bemisia tabaci biotype B in soybean genotypes with different trichome density. Journal of Pest Science, 85, 431-442. https://doi.org/10.1007/s10340-012-0443-0

Vieira, S. S., Lourenção, A. L., Graça, J. P., Janegitz, T., Salvador, M. C., Oliveira, M. C. N. and Hoffmann-Campo, C. B. (2016). Biological aspects of Bemisia tabaci biotype B and the chemical causes of resistance in soybean genotypes. Arthropod-Plant Interactions, 10 , 525-534. https://doi.org/10.1007/s11829-016-9458-4

Villas Bôas, G. L., França, F. H., Ávila, A. C. and Bezerra, I. C. (1997). Manejo integrado da mosca-branca Bemisia argentifolii. Comunicado Técnico, 9. Brasília: Embrapa.

Villas Bôas, G. L. (2005). Manejo integrado de mosca-branca. Comunicado Técnico, 28. Brasília: Embrapa.

Walsh, P. S., Metzger, D. A. and Higuchi, R. (1991). Chelex-100 as a medium for simple extraction of DNA for PCR-based typing from forensic material. Biotechniques, 4, 506-513. 